\title{
COMPLEMENTARY FEEDING - A SHORT REVIEW OF SEVERAL CORRECT PRINCIPLES OF LONG-TERM HEALTH
}

\author{
Laura Florescu, Oana-Raluca Temneanu, Dana-Elena Mindru, Nistor Nicolai \\ “Gr. T. Popa” University of Medicine and Pharmacy, Iasi
}

\begin{abstract}
Nutrition epitomizes the whole range of physiological processes of absorbtion and decomposition of food in the body, as required for growth and development. The debates on the feeding trends are topical, a large number of scientific boards and international committees fully concentrate on the impact of correct feeding on growth and harmonious development, starting even from intrauterine life.

The progressive introduction of half solid and solid food in the infant's diet after 4-6 months, gradually replacing the milk meals previously administered is known as diversified (complementary) feeding. The latest recommendations of the ESPGHAN Committee (European Society for Pediatric Gastroenterology, Hepatology and Nutrition) regarding the moment of switching from an exclusively milk diet to a diet which includes other foods is included in the period of time between week 17 and 26.

The compliance and the collaboration of the family with the doctors are of paramount importance. Considering the present day open access to a lot of information, sometimes without any scientific basis, we believe it is opportune to review briefly the main aspects of the complementary feeding according to the recommendations in the field.
\end{abstract}

Keywords: complementary feeding, infant, diversification principles, complementary food

Nutrition is the science of feeding and its interconnection with health, representing the total number of physiological processes of food absorbtion and decomposing in the human body, processes required for development and growth (1). The growing needs vary by age (the bigger the needs, the smaller the child), the child's health state and individual characteristics. The total energetic intake grows smaller with age (2).

A hyperglucidic diet and/or hyperlipidic one for the infant stimulates lipogenesis, leading to the hypertrophy \pm hyperplasia of the fat cells, the result being obesity in early childhood (3); a hypocaloric diet leads to malnutrition.

"The dietary equilibrium" represents the optimum ratio in diet principles:

* $\mathrm{P}: \mathrm{L}: \mathrm{G}=1: 2: 4-$ in newborn and infant;

* P:L:G = 1:1,2:3,5 - in 1-3 year-old children.

Ensuring a proper diet during the first 2 years of life is the major element in organogenesis, for the development of the immune and the nervous sys- tem. The deficitary growth is associated to low intellectual and cognitive performance and a deficitary immune system (4).

The general recommendations according to WHO (World Health Organization) for a proper nutrition for infants and small children mention that:

- breastfeeding should start as early as possible, one hour after birth;

- the infant should be fed exclusively on breast milk during the first 6 months of life;

- complementary feeding should start at 6 months, while breastfeeding should be kept at least for 2 years.

The process of gradual introduction of half-solid and solid foods in the infant diet after the age of 4 - 6 months, thus replacing little by little milk meals is known as the process of complementary feeding.

A proper complementary feeding requires: choosing the right moment; being adequate; safety conditions; an adequate feeding technique (5). 
The moment when complementary feeding is introduced depends on the child's age, the previous diet and nutrition status. There have been known important debates referring to the optimum moment of complementary feeding, discussing the advantages/disadvantages of early complementary feeding (at $\sim 3$ months) $(6,7)$.

A recent study concentrates on the analysis of feeding trends for infants younger than one year in Rio de Janeiro, Brazil, during 1998-2008. The conclusion is that generally speaking, the tendency is to disregard the norms of complementary feeding (8). The latest recommendations of the ESPGHAN committee on the introduction of solid and halfsolid foods support the age period between week 17 and 26 (9).

From the physiological point of view, the renal function as well as the digestion enter the growingup process after 4 months, so that the infant will tolerate other types of food, apart from the milk he/ she had been fed on until that age (10).

The principles of complementary feeding:

1. introduce a new type of food only when the infant is healthy;

2. the choice of the first complementary food is made depending on the development traits of each infant;

3 . the new food will be gradually introduced 20-30 g/day for a meal of milk, until the meal is totally replaced by the new food;

4. there will be introduced only one type of food every week - at the same meal;

5. in case of digestion disorders (vomiting and/ or diarrhea) the complementary feeding is interrupted and started again in a few days, after the gastrointestinal transit is back to normal;

6. the caloric value of the newly introduced food (lunch) should be higher than that of the food taken out;

7. the number of meals given in a day in complementary feeding should be established according to age, feeling hungry or full and the infant's weight (11).

We should note: the best criterion of success in complementary feeding for an infant is following the growth and development lines.

The child will not be forced to eat the whole portion (there is a risk of anorexia in "opposition") (12). Giving one food which is received with pleasure for all meals disturbs the nutritional equilibrium of the infant. Hydrating between meals is done with unsweetened liquids (tea, boiled and cooled water).
We should take into account that for the infant which receives complementary food, the necessary of liquids is covered by the newly introduced foods if they include soup, vegetables, fruit, yoghurt. There may be given water by spoon-feeding or in small cups after the meal or in between the meals, in appropriate quantities. It is not recommended to give water in bottles. There have been a lot of controversies lately related to the type of water to be given to infants and the consumption of bottled water has been widely encouraged (13).

For the infant exclusively breast-fed and for the infant bottle-fed on different milk formulas, it is recommended to start the complementary feeding after the age of 6 months (14). For the infant bottle-fed on conventional powdered milk/cow milk, it is recommended to start the complementary feeding after the age of $4-4 \frac{1}{2}$ months (from the $5^{\text {th }}$ month of life) (15).

Complementary feeding has an important influence on educating the feeding preferences as well as taste for later in life. Children have a genetic predisposition towards salty and sweet foods and towards rejecting sour and bitter foods (16).

The table below (Table 1) presents a model of complementary feeding and gradually introducing foods and it can be applied to both the exclusively breast-fed infant and combined or bottle-fed infant.

TABLE 1. Ways of introducing foods according to age (11)

\begin{tabular}{|l|l|}
\hline AGE & FOOD \\
\hline $\begin{array}{l}\text { After 4-4 1/2 months } \\
\text { (from the } 5^{\text {th }} \text { month): }\end{array}$ & $\begin{array}{l}\text { gluten-free cereals, fruit puree, } \\
\text { vegetable soup/vegetable puree }\end{array}$ \\
\hline $\begin{array}{l}\text { After 5-6 months } \\
\text { (starting with the } 6^{\text {th }} \\
\text { month): }\end{array}$ & $\begin{array}{l}\text { boiled and well-blended beef/chicken } \\
\text { (20-30 g/day), homemade cottage } \\
\text { cheese/cottage cheese, egg yolk }\end{array}$ \\
\hline After 6 months: & cereals with gluten \\
\hline After 6-7 months: & $\begin{array}{l}\text { Chicken liver (in alternation with egg } \\
\text { yolk and white meat), plain yoghurt }\end{array}$ \\
\hline After 7-8 months: & Cream, polenta \\
\hline After 10 (12) months: & Fish, meatballs \\
\hline
\end{tabular}

\section{The main foods used in complementary feeding}

Cereals are introduced in the infant's diet at around 4-6 months. They are recommended instead of the traditional flour from biscuits or farina or rice flower as in comparison to them, they are enriched with vitamins, minerals, dietary fibers. Cereals are prepared instant and can be combined with fruit puree/cottage cheese/youghurt for the infants with lower weight and those predisposed to malnutrition (2).

We witness nowadays a degree of uncertainty as regards when, how and under what form gluten should be introduced. For years, the ESPGHAN recommendations have been to avoid introducing it 
earlier than 4 months still, it shouldn't be introduced later than 7 months as well as in a gradual manner, in parallel with breastfeeding. Two independent studies published in New England Journal of Medicine in Octomber 2014, reached the conclusion that the age to introduce gluten does not change the risk of developing Celiac disease and that breastfeeding at any age does not give protection against this disease. In this context, a group of experts considered it would be purposeful to present a document proving consensus regarding the introduction of gluten in the diet (17).

Some food producers have introduced probiotics in the products for infants as clinical studies have proven that they strengthen the natural defensive mechanisms and protect the infant from digestive infections (18) (19).

Fruits and vegetables have a low intake of proteins, lipids and variable intake of glucids, but they are rich in minerals, calcium, phosphate, potassium and iron, in combinations which are easily absorbed by the body. The intake of cellulose might irritate the infant's digestive tract, hence at first it is introduced as juice, then as puree/soup/compote. It is also advisable that caution should be taken when giving fruits with allergy potential (raspberry/ strawberry/wild strawberry/kiwi) as they are not recommended before 1 year old.

Vitamins are nutrition factors and are also essential co-factors in a variety of metabolism ways and necessary quantity of vitamins changes from one age to another or due to the presence of certain illnesses. Most vitamins can be synthesized by the body, that is why the diet should be balanced and offer the infant the necessary quantity of vitamins. There are two exceptional situations: vitamin D during the first two years and vitamin K (20).

When the daily diet is established, we should also take into account that minerals are not renewed in the human body that is why they should be taken from the diet (13).

The vegetarian, lacto-vegetarian and raw-vegan diets are not recommended for infants and small children as they do not provide the necessary intake of proteins - essential aminoacids and iron, which are indispensable for an optimum development of a body with special needs for development and growing. That is why it is highly imperative that the diet contain a minimum of $500 \mathrm{ml}$ of human milk or a milk formula and/or diary products (16).

Meat is given after 5-6 months, 20-30 g/day, included in soup/vegetable puree. Chicken/turkey/ beef is recommended, boiled and well-blended. Minced meat as meatballs is introduced after 10-12 months. It has been noticed that foods with a low intake of proteins of high biological value leads to nutritional disequilibrium (21).

Another source of proteins and iron is egg yolk and this will be given to the infant after 5-6 months, 2-3 times/week, combined with soup or vegetable puree; the egg white will be introduced after 1 year, as it is a strong allergen. Chicken/cow liver, boiled and blended, is given after 6-7 months, in a quantity of 20-30 g/day, in soup/vegetable puree, when the infant is not fed on egg yolk or meat. White fish, boiled, is recommended for the infant diet after 10-12 months, as it is a potential allergen.

Diary products will be given as low fat cottage cheese or yoghurt. It is not recommended to overuse fruit yoghurt from the supermarket, as it contains a lot of sugar and it favours obesity and appetite for sweet food. Yoghurt is recommended after 6-7 months, combined with cereals or fruit puree. Cottage cheese is added in complementary feeding after 5-6 months and in hyperprotein diets recommended for dystrophic infants. Traditional Romanian cow cheese (not salty) is given after 8-9 months, in combination with polenta/pasta (as pudding) and fermented cheese after 1 year.

Oil made of corn/olive/sun flower/soy/sesame, rich in unsaturated fat is added to the vegetable puree after 5-6 months (1 tea-spoon/day) with the purpose of increasing the caloric value of the lunch. Butter is rich in saturated fat and cholesterol which gives a predisposition to atheromatosis (the first changes in the veins appear during childhood), that is why it is not recommended to overuse it.

Biscuits can be given after 6 months, powdered, added in fruit puree. White bread is introduced after 8 months if chewing is possible. Pasta (noodles/vermicelli) are used starting with 8 months, boiled in soup.

Honey will be introduced in the diet after 1 year, due to the risk of Clostridium botulinum infection (22), or earlier if the product is treated at high temperature or pressure, so as to neutralize germs and also due to the fact it is a potential allergen.

Industrial products can be a good alternative for the meals made of vegetables or fruit. The control over temperature and preparation time, pasteurization and sterilization eliminate the pathogenic microorganisms which might contaminate the food but they maintain the nutritional value (23).

Practically, an infant on complementary feeding might be given 5 meals (m) x $200 \mathrm{ml}$ or $6 \mathrm{~m} \times 160$ (170) $\mathrm{ml}$. They will be distributed as follows:

- $1 \mathrm{~m} \mathrm{x} \mathrm{200-250} \mathrm{ml} \mathrm{human} \mathrm{milk/milk} \mathrm{formula}$ \pm cereals 
- $1 \mathrm{~m} \mathrm{x}$ fuit puree (apple/peach/apricot) with cottage cheese/cereals

- $1 \mathrm{~m} \mathrm{x}$ vegetable puree with meat/egg yolk/ liver

- $1 \mathrm{~m}$ x yoghurt/cottage cheese and cereals

- $1 \mathrm{~m}$ x 200-250 ml human milk/ milk formula \pm cereals.

Making the change from the exclusively milk diet to the complementary one and spoon feeding requires new behavior situations and habits to which both the mother and the child should adapt. An important aspect is given by the neuromuscular development; at the same time, there are noticed coordinated movements of the lips and the tongue for eating. The new foods will be blended until the first teeth come out, then they will be mashed. After 9 months, the baby takes the food with the hands or uses a spoon with both hands. The liquids and halfsolid foods are best given in cups. After 6-9 months the infant can and it is actually recommended to have one meal per day together with the family.

Some important special situations appear in the case of complementary feeding for premature babies and in these cases there should be taken into account the corrected age as well as in the case of infants with a family history of atopy. Complementary feeding for the infants with family atopy is a widely studied topic whereas the pathology of the allergenic type is in a constant dynamic, considering the use of industrial food on a large scale, to the detriment of ecological food (24-26).

\section{CONCLUSIONS}

Complementary feeding is an important stage in the life of the infant and of the family, having a long-term impact on the harmonious growth and development. The family should be more aware of the importance of cooperation with the doctor specialized in pediatry and following his recommendations in order to enter the new stage of complementary feeding without negative incidents and start a balanced, complete diet, similar to the adult's diet.

For the infants fed exclusively on breastfeeding and for the infants bottle fed on milk formulas it is recommended to start the complementary feeding after 6 months. For the infants bottlea fed on powedered milk or cow milk it is recommended to start the complementary feeding after $4-4 \frac{1}{2}$ months (during the $5^{\text {th }}$ month).

Complementary feeding has an important influence on educating the food tastes and preferences later in life. The mistakes made in feeding during the first year have consequences on the death rate and have an influence on the childhood as well as on adult life.

The special cases which bear importance are the complementary feeding for the premature infants and in their case there should be taken into consideration the corrected age as well as in the case of infants with a family history in atopy. Considering the current trends in adult diets, namely vegetarian, lacto-vegetarian and raw-vegan diets, mention should be made that they are not recommended for infants and small children since they do not ensure the necessary intake of proteins, essential aminoacids and iron.

\section{REFERENCES}

1. Manualul Merck, ediția a XVIII-a, Editura ALL, 2006.

2. Florescu L. Puericultura. Iaşi: Editura "Gr.T. Popa", 2008.

3. Redsell S.A., Edmonds B., Swift J.A., et al. Systematic review of randomised controlled trials of interventions that aim to reduce the risk, either directly or indirectly, of overweight and obesity in infancy and early childhood. Matern Child Nutr. 2015; Apr 20.

4. Orăşeanu D. Nutriția precoce şi sănătatea pe termen lung. Recomandări nutriționale în practica pediatrică, 2013; 10-14.

5. Complementary feeding: report of the global consultation, and summary of guiding principles for complementary feeding of the breastfed child.World Health Organization, 2002.

6. Ciofu C. Diversificarea alimentației. In: Ciofu E.P. Pediatrie tratat, ediția I. Editura Medicală, Bucureşti 2011: 106-107.

7. Alvisi P., Brusa S., Alboresi S., et al. Recommendations on complementary feeding for healthy, full-term infants. Ital J Pediatr. 2015; 41(1):36.

8. Oliveira D.A., Castro I.R., Jaime P.C. Complementary feeding patterns in the first year of life in the city of Rio de Janeiro, Brazil: time trends from 1998 to 2008. Cad Saude Publica. 2014; 30(8):1755-64.

9. Cattaneo A., Williams C., Pallás-Alonso C.R., et al. ESPGHAN's 2008 recommendation for early introduction of complementary foods: how good is the evidence? Matern Child Nutr. 2011; 7(4):335-43.

10. Michaelsen K., Weaver L., Branca F. et al. Feeding and nutrition of infants and young children. Guidelines for the WHO European region, with emphasis on the former Soviet countries. WHO Regional Publications, European Series, No.87, 2003.

11. Florescu L., Balanica G. Puericultură - elemente practice de puericultură pentru copilul 0-3 ani. laşi: Editura “Gr.T. Popa” U.M.F. Iaşi, 2012.

12. Bloj R., Grecu G. Formele clinice ale anorexiei nervoase în funcție de vârstă. Acta Medica Transilvanica 2009; No.2.

13. Florescu L. Alimentația sugarului, Alimentația copilului 1-3 ani. În: Anton-Păduraru D.T. PEDIATRIE - Suport de lucrări practice pentru 
specializarea nutriție şi dietetică, Editura "Gr.T. Popa” laşi, 2014: 44-69.

14. Agostoni C., Decsi T., Fewtrell M. et al. Medical Position Paper Complementary Feeding: A Commentary by the ESPGHAN. Journal of Pediatric Gastroenterology and Nutri 2008; 46:99-110.

15. Ministerul Sănătății - Institutul pentru Ocrotirea Mamei şi Copilului „Prof. Dr. Alfred Rusescu“, Principii în alimentația copilului şi gravidei: Îndrumar pentru furnizorii de servicii de sănătate la nivel comunitar, Ed. a 2-a, rev. Bucureşti: Editura MarLink, 2007.

16. Baciu G. Alimentatia complementara. Recomandări nutriționale în practica pediatrică 2013; 35-38.

17. Ribes Koninckx C., Dalmau Serra J., Moreno Villares J.M. et al. The introduction of gluten into the infant diet. Expert group recommendations 2015; Apr 22.

18. Zhu H.J., Cai Y. Effects of bacillus bifidus supplementation on the immunity in very-low-birth-weight infants. Zhongguo Dang Dai Er Ke Za Zhi. 2011; 12:944-6.

19. Agostoni C., Axelsson I., Braegger C. et al. Comitetul ESPGHAN pentru nutriție: Probioticele în produsele dietetice pentru copii: comentariul comitetului ESPGHAN pentru nutritie, Jurnalul de Gastroenterologie şi Nutriție Pediatrică 2004; 38:365-374.
20. Ministerul Sănătății - Institutul pentru Ocrotirea Mamei şi Copilului „Prof. Dr. Alfred Rusescu“, Protocoale pentru profilaxia anemiei şi rahitismului la copil. Bucureşti: Editura Oscar Print, 2010.

21. Pantoja-Mendoza I.Y., Meléndez G., Guevara-Cruz M., et al. Review of complementary feeding practices in Mexican children. Nutr Hosp. 2014; 31(2):552-8.

22. Godart V., Dan B., Mascart G. et al. Infant botulism after honey exposure. Arch Pediatr. 2014; 21(6):628-31.

23. Nestle. Compendium de nutritie, 2012.

24. Koletzko B., Shamir R., Ashwell M. Early Nutrition Academy (ENA); European Society for Paediatric Gastroenterology, Hepatology and Nutrition (ESPGHAN).Quality and safety aspects of infant nutrition. Ann Nutr Metab. 2012; 60(3):179-84.

25. Muraro A., Halken S., Arshad S.H. et al. EAACI Food Allergy and Anaphylaxis Guidelines Group. EAACl food allergy and anaphylaxis guidelines. Primary prevention of food allergy. Allergy. 2014; 69(5):590-601.

26. Alexoae M., Goția S. Controverse privind alimentația sugarului atopic. Revista română de pediatrie, 2010; LIX(4): 242-248. 